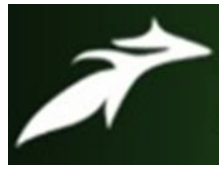

Anusha Gandla et al, International Journal of Advances in Agricultural Science and Technology,

Vol.7 Issue.11, November-2020, pg. 70-77

ISSN: 2348-1358

Impact Factor: 6.057

NAAS Rating: 3.77

\title{
The Problems and Prospects of Women Entrepreneurs
}

\author{
Ms. Anusha Gandla*; Dr. Syed H. Mazhar** \\ *Research Scholar, Dept. of Ag. Extension \& Communication, SHUATS, Prayagraj \\ **Associate Professor, Dept. of Ag. Extension \& Communication, SHUATS, Prayagraj \\ DOI: 10.47856/IJAAST.2020.v07i11.010
}

\begin{abstract}
Women are one of the most relevant untapped resources if you talk about entrepreneurship. Female entrepreneurship is gaining attention and importance in light of the evidence of the importance of new business creation for economic growth and development. Entrepreneurship refers to the act of setting up a new business so as to take advantages from new opportunities. Entrepreneurs are responsible for shaping the economy and they help in creation of new wealth and new jobs by inventing new products, process and services. We all understand that economic development of the today's woman is crucial for economic development of any country specially a country like India. The women today have emerged as a key player in economic development of the nations. However this transformation of society is far from over and the women entrepreneurs not only face difficulties while starting up an enterprise but also during the running phase. Globally, they have become a key player in sustaining both social development and economic growth. There are a number of socio-economic hurdles faced by the women while they attempt to venture into setting up and running their own enterprises. In this paper, an attempt has been made to study the opportunities and challenges related with entrepreneurship that the woman of our country faces in the present times.
\end{abstract}

Keywords: prospects, risk bearing

\section{Introduction:}

An entrepreneur is a person who is involved in economic activity and takes an initiative to start a business with innovative ideas. Entrepreneurship provides huge opportunities for self-expansion as well as serves the society. All over the world, entrepreneurs provide vast employment opportunities by setting up Micro, Small and Medium enterprises in urban, semi - urban and rural areas for uplifting the living standard of people. The phenomenon of women entering the entrepreneurial arena is in the early stage as businesses have been male dominated and women have always engaged in homely affairs i.e. cooking and nurture the family and children. Over the last few years, the scenario has changed and the women have come to the forefront as not only memorable but also as inspirational entrepreneurs. Entrepreneurship as such is not bound by the class, religion, community, gender or age and hence any person can start a business today. In past few years, women entrepreneurs have been involved significantly in the development and social progress of the country due to industrialization, urbanization along with education and 


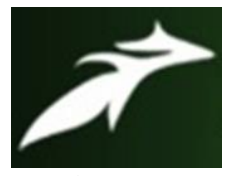

Anusha Gandla et al, International Journal of Advances in Agricultural Science and Technology, Vol.7 Issue.11, November-2020, pg. 70-77

ISSN: 2348-1358

Impact Factor: 6.057

NAAS Rating: 3.77

awareness. This opens up ample opportunities for the nation, society and the family. Setting up their own ventures not only makes them self-sufficient and self-dependent but also enables them to create their own social identity. This way they have been able to achieve work-life balance and contributed to the satisfaction of their customers by involving themselves in the innovation of the products. also they have been able to empower people economically. Various sources of data confirm the contribution of this new generation of entrepreneurs i.e. the women entrepreneurs play a crucial role in the economies across the world. Special incentives and subsidies have been provided to the women - owned MSMEs by the government of India, yet there is a huge gap existing between the male and female entrepreneurs is to be covered. Obstacles are faced at every stage of setting up business by this group of entrepreneurs.

Women's entrepreneurship needs to be studied separately for few main reasons. The reason is that women's entrepreneurship has been recognized during the last decade as an important untapped source of economic growth. Women entrepreneurs create new jobs for themselves and others and by being different also provide society with different solutions to management, organization and business problems as well as to the exploitation of entrepreneurial opportunities. However, they still represent a minority of all entrepreneurs. Thus there exists a market failure discriminating against women's possibility to become entrepreneurs and their possibility to become successful entrepreneurs. This market failure needs to be addressed by policy makers so that the economic potential of this group can be fully utilized. The purpose of the paper to examine the constraints and opportunities facing female entrepreneurship in developing countries at micro- and macro-level perspectives and seeks to provide a detailed account of opportunities and constraints bought by entrepreneurship.

\section{Objective:}

\section{To assess the problems of the women entrepreneurs}

2. To assess the prospects of the women entrepreneurs

\section{Methodology}

A descriptive research design was followed. The study was conducted in Anantapur district of Andhra Pradesh state during the year, 2019-20. Anantapur district of Andhra Pradesh was selected, out of 63 mandals, three mandals is selected purposively and four villages were selected from each mandal for the study. Respondents were selected from the village by following proportionate random sampling method. Thus, 120 farmers constituted as sample for the study. 


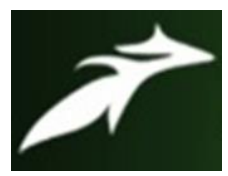

Anusha Gandla et al, International Journal of Advances in Agricultural Science and Technology, Vol.7 Issue.11, November-2020, pg. 70-77

ISSN: 2348-1358

Impact Factor: 6.057

NAAS Rating: 3.77

Data were collected by pre-tested schedule followed by personal interview method. For the purpose of statistical analysis of the coded data, appropriate statistical tools were used viz., frequency and percentages and ranking.

For the present study the 'constraint' was operationalized as the something that limits or controls in operating the enterprises by the women entrepreneurs. Based on the exhaustive review of literature, interaction with women entrepreneurs during pretesting and by taking experts opinion, a total of 36 problems were identified and arranged under five categories viz., 10 socio personal, 9 financial, 5 technical, 8 marketing and 4 infrastructure constraints were included to analyze the constraints. The women entrepreneurs were asked to rate each constraint on a three point continuum viz., major, minor and not a constraint with the scores of 2, 1 and 0 respectively. Then the ranking was given to the constraints under each category based on the magnitude of mean scores obtained.

\section{RESULTS \& DISCUSSION}

\section{To access the problems and prospects of women entrepreneurs}

\section{Problems / constrains of women entrepreneurs}

The constraints in operating the enterprises by the women entrepreneurs were classified into four major types which were linked with socio personal, financial, technological, marketing and infrastructure constraints.

The table 1 explicitly depicted the constraints, were ranked based on the order of highest percentage obtained within each major type of constraints.

\begin{tabular}{|l|l|l|l|l|}
\hline I. & Socio personal problems & Frequency & Percentage & Ranking \\
\hline 1. & $\begin{array}{l}\text { No support from other family } \\
\text { members }\end{array}$ & 75 & 62.5 & I \\
\hline 2. & Indifferent attitude of society & 70 & 58.33 & II \\
\hline 3. & $\begin{array}{l}\text { Conflict due to dual } \\
\text { responsibilities }\end{array}$ & 67 & 55.83 & III \\
\hline 4. & Lack of self confidence & 63 & 52.5 & IV \\
\hline 5. & Male dominance & 62 & 51.66 & V \\
\hline
\end{tabular}




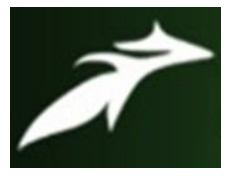

Anusha Gandla et al, International Journal of Advances in Agricultural Science and Technology, Vol.7 Issue.11, November-2020, pg. 70-77

ISSN: 2348-1358

Impact Factor: 6.057

NAAS Rating: 3.77

\begin{tabular}{|c|c|c|c|c|}
\hline 6. & $\begin{array}{l}\text { Lack of recognition } \\
\text { \&appreciation }\end{array}$ & 62 & 51.66 & VI \\
\hline 7. & No risk bearing capacity & 60 & 50 & VII \\
\hline 8. & Lack of freedom & 59 & 49.16 & VIII \\
\hline 9. & Difficulty in travelling & 56 & 46.66 & IX \\
\hline 10. & Fear of social security & 55 & 45.83 & $\mathrm{X}$ \\
\hline II. & Financial Problems & & & \\
\hline 1. & Limited working capital & 76 & 73 & $\mathrm{I}$ \\
\hline 2. & $\begin{array}{l}\text { Shortage of capital in starting the } \\
\text { business }\end{array}$ & 73 & 60.83 & II \\
\hline 3. & Lack of own funds \&resources & 72 & 60 & III \\
\hline 4. & Negative Attitude of Banks & 65 & 54.16 & IV \\
\hline 5. & $\begin{array}{l}\text { Lack of education in financial } \\
\text { assistance }\end{array}$ & 63 & 52.5 & V \\
\hline 6. & Improper utilization of funds & 63 & 52.5 & VI \\
\hline 7. & Delay in sanctioning the loan & 62 & 51.66 & VII \\
\hline 8. & Lack of government assistance & 60 & 50 & VIII \\
\hline 9. & Inadequate loan & 59 & 49.16 & IX \\
\hline III. & Technological problems & & & \\
\hline 1. & $\begin{array}{l}\text { Non availability of skill } \\
\text { manpower }\end{array}$ & 80 & 66.66 & I \\
\hline 2. & $\begin{array}{l}\text { Not getting the opportunity of } \\
\text { entrepreneurship training }\end{array}$ & 77 & 64.16 & II \\
\hline 3. & $\begin{array}{l}\text { Lack of adequate skill to start } \\
\text { new venture }\end{array}$ & 72 & 60 & III \\
\hline 4. & $\begin{array}{l}\text { Experience workers leave the } \\
\text { unit after sufficient exposure }\end{array}$ & 68 & 56.66 & IV \\
\hline 5. & $\begin{array}{l}\text { Lack of knowledge of various } \\
\text { government schemes }\end{array}$ & 64 & 53.33 & $\mathrm{~V}$ \\
\hline IV. & Marketing problems & & & \\
\hline 1. & $\begin{array}{l}\text { Shortage of manpower for selling } \\
\text { the products }\end{array}$ & 79 & 66 & $\mathrm{I}$ \\
\hline 2. & $\begin{array}{l}\text { Heavy competition with big } \\
\text { enterprises }\end{array}$ & 76 & 63.33 & II \\
\hline 3. & $\begin{array}{l}\text { Lack of knowledge of how to } \\
\text { market the product }\end{array}$ & 71 & 59.16 & III \\
\hline 4. & $\begin{array}{l}\text { Inappropriate price for the } \\
\text { products }\end{array}$ & 70 & 58.33 & IV \\
\hline
\end{tabular}




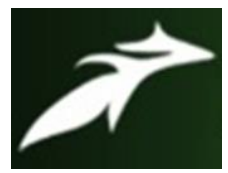

Anusha Gandla et al, International Journal of Advances in Agricultural Science and Technology, Vol.7 Issue.11, November-2020, pg. 70-77

ISSN: 2348-1358

Impact Factor: 6.057

NAAS Rating: 3.77

\begin{tabular}{|c|l|l|l|l|}
\hline $\mathbf{5 .}$ & Late payment by the customers & 68 & 56.63 & V \\
\hline $\mathbf{6 .}$ & $\begin{array}{l}\text { Fluctuation in the demand \& } \\
\text { price of the product }\end{array}$ & 67 & 55.83 & VI \\
\hline $\mathbf{7 .}$ & $\begin{array}{l}\text { Difficulty to sell the product in } \\
\text { market }\end{array}$ & 62 & 51.66 & VII \\
\hline $\mathbf{8 .}$ & Exploitation by middlemen & 57 & 47.5 & VIII \\
\hline V. & Infrastructure problems & & 62.5 & I \\
\hline $\mathbf{1 .}$ & Inadequate space \& building & 75 & 60.83 & II \\
\hline $\mathbf{2 .}$ & Inadequate power supply & 73 & 56.66 & III \\
\hline $\mathbf{3 .}$ & $\begin{array}{l}\text { Inadequate communication } \\
\text { facility }\end{array}$ & 68 & 47.5 & IV \\
\hline $\mathbf{4 .}$ & $\begin{array}{l}\text { Shortage of equipments or } \\
\text { machines }\end{array}$ & 57 & & \\
\hline
\end{tabular}

In consideration to socio personal problems 'no support from other family members'

(62.5) was ranked first and felt as the most problematic by a huge majority of women entrepreneurs. It was followed by decreasing order of percentage of the problems as in different attitude of the society, conflict due to dual responsibilities, Lack of self confidence

Male dominance, Lack of recognition \&appreciation, No risk bearing capacity, Lack of freedom, Difficulty in travelling, Fear of social security.

In financial constraints, very large majority of the women entrepreneurs felt that 'limited working capital' as a foremost constraint and it was ranked first. 'shortage of capital in starting the business' was ranked second and was considered as one of the major constraint by most of the women entrepreneurs. A moderate majority of the women entrepreneurs observed 'lack of own funds \&resources' as a major constraint.it was followed by decreasing order of percentage of the problems Negative Attitude of Banks Lack of education in financial assistance, Improper utilization of funds, Delay in sanctioning the loan, Lack of government assistance, Inadequate loan.

Regarding technological constraints 'non availability of skill manpower' (66.66) ranked first and was felt as a prominent constraint by the most of women entrepreneurs. It was followed by Not getting the opportunity of entrepreneurship training, Lack of adequate skill to start new venture, Experience workers leave the unit after sufficient exposure, Lack of knowledge of various government schemes.

In marketing constraints, very large majority of the women entrepreneur 'shortage of manpower for the selling products' (66) as a foremost constraint and it was ranked first. 'heavy competition with big entreprises' (63.33) was ranked second and was considered as one of the major constraint by most of the women entrepreneurs. A followed by Lack of knowledge of how to market the product, Inappropriate price for the products, Late payment by the customers, 


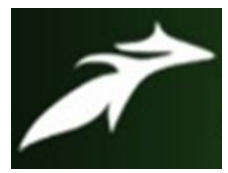

Anusha Gandla et al, International Journal of Advances in Agricultural Science and Technology, Vol.7 Issue.11, November-2020, pg. 70-77

ISSN: 2348-1358

Impact Factor: 6.057

NAAS Rating: 3.77

Fluctuation in the demand \& price of the product, Difficulty to sell the product in market, Exploitation by middlemen.

Regarding infrastructure constraints 'Inadequate space \& building' (62.5) ranked first and was felt as a prominent constraint by the most of women entrepreneurs. It was followed by Inadequate power supply (60.83), Inadequate communication facility (56.66), Shortage of equipments or machine(47.5).

This finding was in agreement with the findings of Rao (2011), Sreeram (2013), Vijayabharathi and Masthani (2014) and Mubeena (2017).

\section{Prospects for Development of Women Entrepreneurs:}

- Education is a boon to mankind, while lack of education to a person is a bane now-a-days. Throughout the world, we can observe that the ratio of women entrepreneurs is growing tremendously. The emergence as well as development of women entrepreneurs is quite visible in India and their over-all contribution to Indian economy is also very significant. Today the role of Women entrepreneur in economic development is inevitable because women are entering not only in selected professions but also in professions like trade, industry and engineering.

The industrial structure and the enterprises are undergoing a radical change. Information Technology has transformed the very technique of doing business. Individually, business ownership provides women with the independence they crave and with economic and social success they need. Nationally, business ownership has great importance for future economic prosperity. Globally, women are enhancing, directing, and changing the face of how business is done today. Ultimately, female business owners must be recognized for who they are, what they do, and how significantly they impact the world's global economy.

Women should be considered as specific target group for all development programmes. Govt. should extend better educational facilities and schemes to women folk. Adequate training programs on management skills should be provided to women community. Encourage women's participation in decision making. Vocational training should be extended to women community to enable them to understand the production process and management.

- Training on professional competence and leadership skills should be extended to women entrepreneurs. Activities in which women are trained should focus on their marketability and profitability. State Finance Corporations and financing institutions should permit by statute to extend purely trade related finance to women entrepreneurs. And lastly women's development corporation has to gain access to open-ended financing.

The findings were in accordance with the studies conducted by Sweety Gupta (2015), sonu garg (2017). 


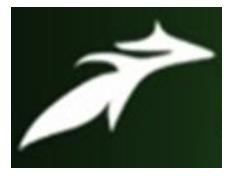

Anusha Gandla et al, International Journal of Advances in Agricultural Science and Technology, Vol.7 Issue.11, November-2020, pg. 70-77

ISSN: 2348-1358

Impact Factor: 6.057

NAAS Rating: 3.77

\section{Conclusion}

Women entrepreneurship in India faces many challenges and requires a radical change in attitudes and mindsets of society. Therefore, programs should be designed to address changes in attitude and mindset of the people. It is important to promote entrepreneurship among women to improve the economic situation of the women. This can be made possible with the help of education as education is a powerful tool in bringing out the entrepreneurship qualities in a human being. Moreover, attempts to motivate inspire and assist women entrepreneurs should be made at all possible levels. Proper training should be given to the women by establishing training institutes that can enhance their level of work-knowledge, risk-taking abilities, enhancing their capabilities. After setting up training institutes, there should be continuous monitoring, improvement of training programs so that they can improve upon the quality of the entrepreneurs being produced in the country. Undoubtedly the women participation rate in the field of entrepreneurship is increasing rapidly. However, efforts need to be taken at larger scale to give the position in the field of entrepreneurship that they deserve. The actions \& steps that has been taken by the government sponsored development activities have benefited only a small strata of society and more needs to be done in this area. Effective steps need to be taken to have entrepreneurial awareness and skill development to women.

\section{References}

[1]. Ahl H(2016), "why research on women entrepreneurs needs new directions" entrepreneurship theory and practice, September 1, 2016.

[2]. Datta B.P. (2012), "empowering women through social entrepreneurship: case of a women's cooperative in India" entrepreneurship theory and practice, special issue on women's entrepreneurship, vol.36 no 3, pp. 569-587, 2012.

[3]. De vita L (2014), "women entrepreneurs in and from developing countries: from the evidences from the literature" European management journal, Elsevier vol. 32(3), pages 451-460,2014.

[4]. Garg S(2017), “ problems and prospects of women entrepreneurship - a review of literature" IOSR journal of business and management(IOSR-JBM), VO 19, issue 1. PP 55-60.

[5]. Goyal M (2011), "women entrepreneurship in India-problems and prospects" international journal of multidisciplinary research 1 (5), 195-207, 2011.

[6]. Gupta S (2015), “opportunities \& challenges faced by women entrepreneurs in India"

[7]. IOSR Journal of Business and Management (IOSR-JBM), Volume 17, Issue 8.Ver. III (Aug. 2015), PP 69-73.

[8]. kumar (2015), "a study on women entrepreneurs in India" International journal of applied science and technology research excellence vol.5 issue 5, Novemberdecember,2015. 


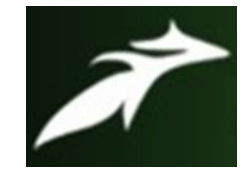

Anusha Gandla et al, International Journal of Advances in Agricultural Science and Technology,

Vol.7 Issue.11, November-2020, pg. 70-77

ISSN: 2348-1358

Impact Factor: 6.057

NAAS Rating: 3.77

[9]. Singh G, Rakesh Belwal (2008), "entrepreneurship and SMEs in ethopia: evaluating the role ,prospects and problems faced by women in this emergent sector" gender in management :an international journal 23(2), 120-136, 2008.

[10]. Tambunan (2009), "women entrepreneurship in Asian developing countries: their development and main constrains" journal of development and agricultural economics 1 (2), 027-040, 2009. 